DOI: 10.1515/pof-2016-0005

VOLUME 8, ISSUE 1, 2016

ISSN: 2036-5438

\title{
U.S. States' fiscal constraints and effects on budget policies
}

by

Mario Iannella*

Perspectives on Federalism, Vol. 8, issue 1, 2016 


\begin{abstract}
The article looks at fiscal constraints adopted by the U.S. States. It questions the ability of those rules to determine sound budgetary policies. To assess this point it analyses, in the general part, the major kind of constraints so far adopted. Of each major category the focus is upon institutional weaknesses that create the room for the adoption of circumventing practices. The following section focuses instead on three case studies, to show examples of the way in which the constraints influenced policy-making without mining the ability of government to adopt unbalanced budgetary policies. The weaknesses are combined with the adoption of a deferential approach by the Courts that generally legitimized the accounting devices adopted by the States. The outcome is a system in which budget policies are influenced by several factors that go beyond the institutional framework. On the other side, legal boundaries create distortions and unwanted effects in policies implemented by the States.
\end{abstract}

Key-words

Balanced Budget Rules, U.S. States' Budget Constraints, Effectiveness of fiscal constraints, Effects on BBRs upon States policy, Courts' evaluation of budget constraints 


\section{Introduction}

The scope of this article is the analysis of fiscal constraints adopted by States in the U.S.A, looking particularly at the effectiveness of the rules they included, and the way in which they were able to influence fiscal policies. Two aspects in particular can be considered reasons for our interest in this matter: the different behaviour of States and the influence of their fiscal institutions on this, and the development of large state deficits, notwithstanding the constraints which were meant to limit this development (Poterba 1997: 56). In particular, during the last economic downturn the budget troubles of the States raised serious questions about the ability of some of them to afford their economic obligations. These concerns have affected the Federal Government, and have been addressed in the scholarship. The first adopted a series of measures that directly, or indirectly, helped the States to be able to afford the costs of the economic downturn, amongst which the Patient Protection and Affordable Care Act ${ }^{\mathrm{I}}$ and the American Recovery and Reinvestment Act ${ }^{\mathrm{II}}$ played a key role. The scholarship focused instead on the availability of different tools to solve the debt crisis, such as the creation of a State Bankruptcy mechanism (see as an example Skeel 2012). This article takes advantage of the ending of harsher times to look at the picture from a more detached standpoint. This allows us to fulfil the purpose of analysing the institutional framework of budgetary policies that have been placed under particular stress in the fiscal crisis.

In order to consider the issues that lie behind budgetary constraints, it is germane to note a preliminary point and clearly focus on the key problem of the instruments. This preliminary remark is connected to the origins of fiscal constitutional limitation among the U.S. States. The first wave of limitations dates back to the financial crisis of the1840s and is particularly connected to the default of several States. ${ }^{\text {III }}$ Moreover, after the Civil War, the new States admitted to the Union adopted a Constitution that included a debt limit clause (Ratchford 1941: 122). This element is relevant in two directions. On the one hand, the reasons that pushed for the constitutional brakes are all of an internal nature: this marked a clear difference with the contemporary European examples. In fact, the Federal Government did not intervene in the adoption of the budgetary constraints. Moreover, no 
duty or mandate to impose them existed upon the States. ${ }^{\text {IV }}$ On the other hand, the gradual and internal formation of these rules has resulted in broad differences between the tools States used and the goals that they tried to achieve. It links us to the key problem of the constraints: their effectiveness in binding the behaviour of the different administrations and their effects on the policies adopted by public governments. While several States have encountered financial difficulties, overall debt exposition in terms of GDP percentage remains low: moreover fiscal discipline varies considerably between States. This forces us to introduce some factors that could be relevant in assessing the effectiveness, and the effects, of the constraints. Firstly, several studies connect different rules to different behaviour among States: ${ }^{V}$ it is important to note that what appear as influencing factors are not only rules that directly affect the budget, but also certain States' constitutional provisions such as the way in which the judges of the States' Supreme Court are individuated. ${ }^{\mathrm{VI}}$ Other studies have focused on the implicit purpose of these rules: particularly looking at the way in which they are perceived, by the market, and by the States that adopted them, and how this element modified the financing debt costs. ${ }^{\text {VII }}$ Other areas of scholarship note that the effectiveness of the constraints could be influenced by the politics within the States, for example being more effective in the very States that, for political and cultural reasons, have less need for them. ${ }^{\text {VIII }}$

The intent of this article is to focus on aspects of each kind of constraint that erode their effectiveness. This phenomenon is created because of two elements: deficiencies in the articles of States' Constitutions or laws providing them and the interpretative approach of the Courts when challenged. Section II analyses the different budget constraints adopted by the States, grouping them in four categories: public purpose requirements, debt limits, tax and expenditure limits and budget bill rules. In each one we offer an interpretation of the weakness of the provisions and of the constraints that States adopted to circumvent them. Section III evaluates the consequences and the roles that these rules can generate in the budgetary process. The analysis of California, New York and Illinois will offer a useful perspective on the coherence of this approach. The States differ as regard to the constraints provided by their institutional framework. They all face severe fiscal crisis, notwithstanding that the budgetary, economic and political issues that they face are quite different. The analysis of these States allows us to assess the concept of the general inability of those rules to determine sound budgetary policy. In section IV we move on to a 
summary of the interpretative approach taken by the courts as regards the budget constraints; the intent here is to describe an overall trend that contributes to defining the general weakness of those clauses. Lastly, in Section V, we conclude by assessing some points on the effectiveness of the constraints and the role they play in determining the budget policies of States.

\section{A Taxonomy of Budget Constraints. Weakness and Ways of Circumventing}

States have adopted very different budget constraints, and thus the first element to be analysed is the typology of those adopted and their effectiveness. As we have also noted, constraints that were implemented were not a single moment's choice, but the result of a progressive modification of State Constitutions, often in response to the perceived weakness of earlier constraints. ${ }^{\text {IX }}$ The research summarizes four major categories of these, and to fulfil the purpose of our research in each subsection we try to highlight three elements: (1) features and scopes; (2) weakness; (3) ways of circumventing.

\subsection{Public purpose requirements}

The first type of constraint provided for in many State Constitutions was the public purpose requirement, ${ }^{\mathrm{x}}$ usually considered the weakest form of budgetary constraint. It basically consists of an explicit limit on the authority of the State Government to provide financial assistance to private enterprises (Rubin 1993: 143). The origins of these limitations date to the crisis of the 1840s, when the finances of most States collapsed due to the large amount of debt contracted to finance private projects, - projects that failed to generate the expected revenues. ${ }^{\mathrm{XI}}$ The scope of the provisions implemented in consequence was to protect the public finance from uses that were not considered to be of public interest. ${ }^{\text {XI }}$ The courts originally adopted an approach of strict scrutiny of these requirements, but they gradually eroded the constraints, beginning in the 1930s by admitting certain forms of development assistance, and in the decades after World War II by allowing some forms of direct government assistance to private firms. ${ }^{\text {XIII }}$ The reasoning of the courts is marked by their deference to the legislatures in determining the nature of the public interest that the Constitutions require, insofar as the limitations operate only in extremely clear cases where 
the public interest is absent, while also in doubtful cases the deferential approach works in favour of the legislatures. ${ }^{\mathrm{XIV}}$ This explains why the public purpose requirement, in the absence of judicial enforcement, is now considered a weak limitation or a merely theoretical one. ${ }^{\mathrm{xv}}$

\subsection{Debt limits}

The majority of State Constitutions include limitations on debt (see e.g. Sterk and Goldman 1991: 1315), which can generally be divided between procedural and substantial. In the latter case the constraints range from a general prohibition of debt, ${ }^{\mathrm{XVI}}$ to an amount limit, ${ }^{\text {XVII }}$ to a cap using as reference wealth, revenues, ${ }^{\text {XVIII }}$ or property -particularly for local government. ${ }^{\text {XIX }}$ However, the more common debt limitations have a procedural nature. A very common one used is the enforcement of the requirements for approval, through a majority in the legislature, or as a voters' referendum, or in some combination of these. ${ }^{\mathrm{xx}}$ Some constitutions combined this requirement with substantive debt limitations. ${ }^{\mathrm{XXI}}$ It is important to note that given the simple majority requirements in many State Constitutions for approving constitutional amendments, substantial limitations could also be considered to be procedural. Here the case of Alabama is illuminating, as it had a strong constitutional requirement ${ }^{\mathrm{XXII}}$ and numerous amendments authorizing bonds (see White 2002: 561-565). The passive force of constitutions imposing debt limitations - considered as the procedural requirements for transformations - becomes in fact the measure of the strength of the debt limitations (in this way, see Briffault 2003: 916-917).

The main issue about debt limit was the breadth of their application. ${ }^{\text {XIII }}$ The constraints were generally designed to limit the contracting of debt to which state and local governments could respond with "full faith and credit": the debt limited - both in substantial and in procedural terms - is the one that takes the form of an obligation covered by the overall revenue capacity of the government. ${ }^{\text {xxI }}$ So, the State avoided the application of the constraints by developing several means to borrow without implicating their "full faith and credit" and full revenues' coverage. ${ }^{\mathrm{xx}}$ The first tool adopted was revenue bonds: their emission was originally financed through giving to creditors the gains connected to the project - as for example a toll on bridge construction - to repay the contracted loan. The creation of a special fund to manage the project was considered by the courts as a valid reason to retain these debts not subject to the limits (see Ratchford 
1941: 446-466). Progressively, however, the connection between project, bond and revenue has been eroded: the courts started to adopt a reasoning that also considered that new revenue sources or a percentage of an existing one could be reserved to this kind of project, if it could cause a relevant increase in the amount of the same. ${ }^{\text {XxvI }}$

The other way to circumvent the debt limitation was to combine the restricted applicative perimeter of the constraint with a contractual form, through lease-financing and subject-to-appropriation debt: the bonds were emitted by private firms or public authorities to finance building activities - in the lease model - or projects that the government decided to entrust to them. At the same time the State made a lease contract for the use of the infrastructure or the services provided, that is used to cover the cost of the debt. The courts considered that the financial activities of these entities were not subject to the debt limits - even when they were fully public in terms of both ownership and management because they lacked authority over taxes and expenditures of the government and so of the "full faith and credit" requirement. XxvII At the same time the contract made by the government is not considered debt - and thus subject to the constraints - when directly connected, as an amount, to the debt service costs of the authority. This arose from different reasoning: from the nature of a payment for a service, ${ }^{\mathrm{XXVIII}}$ to the element that they are annually subjected to the budget and, particularly, to the annual legislative appropriation. ${ }^{\text {xxIx }}$ Moreover, in the subject-to-appropriation debt the similarity to a loan is particularly strong: these are generally connected to a project of a public authority or a service provided and the annual financing from the government is individuated in the debt costs. The court, in particular in this case, had to strongly evaluate two elements to consider this kind of contract external to the debt concept inherent in the constraint: namely the procedural element of the appropriation and the substantive element of annual limited liability. ${ }^{\mathrm{xx}}$ In fact, the only purpose of this instrument is to avoid the accounting of the operation as borrowing in the budget, and to consider in it only the annual finance cost to the public authority: the purpose of the entire operation is to circumvent the State Constitution (Briffault 2003: 921-922). This is confirmed by the evaluations of rating agencies, which considered these instruments as debt issuance (see as example Marino and Waddell 2001). Moreover, the same courts, whilst recognizing the formal reason for excluding these contracts from the debt limitations, stated that they are well aware of the nature of borrowings that they cover on a substantial ground. ${ }^{\text {xxxI }}$ Judgements on those 
measures have created conflicts inside Supreme Courts; in the end, only the New Jersey Supreme Court took a more rigid position. In Lonegan v. State, the subject-toappropriation was saved only for the purposes of the projects - educational ones, particularly enforced in the State Constitution -, while on a procedural ground the Court noted the effect of alteration of the debt limitation clause that comes following these procedures. $^{\text {XxxII }}$

The application of such circumventing instruments has seriously eroded the effectiveness of debt limit norms: in quantitative terms, between two-thirds and threequarters of the total local and State indebtedness is contracted using them (according to Valente et al. 2001: 647). The effects are so broad that several authors have pointed out the absence of any evidence of an impact of these norms upon level of debt (Clingermayer and Wood 1995: 116), and noted that the procedural limits often become mere formal obstacles, considering that State Governments, unable to pass policies following the reinforced procedures, made the same borrowing policies using circumventing techniques (see Gillette 2004: 13-17). However, there are consequences to this kind of institutional compromise: to avoid debt limits, States and local governments have gradually surrendered more and more of their powers and functions to public authorities or agencies (see Bunch 1991).

\subsection{Tax and Expenditure Limits}

In contrast to the previous categories, limitations on tax and expenditure are newer and less widespread among the States. While almost all State Constitutions provide regulations for certain aspects of the taxation regime, only half of them provide any substantive or procedural constraints on levels of taxation or spending (see Hellerstein and Hellerstein 1997: 34). Moreover, within these tax limits, the main focus has generally been on the limitation of property tax, while few State Constitutions have limited sales, xxxII income, ${ }^{\mathrm{XxXIV}}$ or general taxation. ${ }^{\mathrm{XxXV}}$ These limits may concern the tax rate, ${ }^{\mathrm{XxXI}}$ annual variations, ${ }^{\mathrm{XXXVII}}$ or expenditure financed with own revenues. ${ }^{\text {XXXVIII }}$ In procedural terms, the focus has been largely on approval by qualified majorities or through a referendum of voters. ${ }^{\text {XxxIx }}$ This kind of limitation became widespread after the approval in 1978 of California's Proposition 13, which combined a substantial cap on property taxes, limits to diminish inflation effects upon properties, and procedural requirements. ${ }^{\mathrm{XL}} \mathrm{In}$ the following 
years, several States introduced into their constitutions some of these limitations, or a combination of them. ${ }^{\text {XLI }}$ Some States, - like Michigan ${ }^{\text {XLII }}$ and Missouri ${ }^{\text {XLIII }}$ - went further, imposing both procedural and substantial limits on overall taxation. The following step, in a significant number of States, was the adoption of expenditure and revenue limitations connected to extra budgetary factors, such as population or economic growth, which could be combined with restrictions on future modification based on special rules for approval. $^{\text {XLIV }}$

The impact of these limits on property taxes was particularly pronounced (see Sexton et al. 1999: 107). However, the overall influence on the level of taxation and expenditures seems to have been limited (see, e.g., Shadbegian 1996). One of the main consequences of these kinds of requirements has been the development of forms of revenue that are not considered taxes, such as fees, charges, and special assessments (see Galles and Sexton 1998). Notably, while the courts generally enforced the limitations on property tax, they have been less restrictive with regard to limitations on other forms of revenue, ${ }^{\mathrm{XLV}}$ where a permissive interpretation was generally adopted with regard to special assessments, fees and charges. In all these cases the courts identified the absence of at least one of the features needed to identify something as a tax: coercion and potential for redistribution. ${ }^{\mathrm{XLV}}$ The courts also generally validated the loss of the connection between a type of revenue and its purposes, consenting to allow the financing of an increasing number of activities through those non-tax revenues. ${ }^{\text {XLVII }}$ While this interpretative trend was carried out to differing degrees among various courts, it is possible to identify an overall reduction in the applicability perimeter of tax limitation, as a result of the development of these policies by State Legislatures and the consent of courts to them. ${ }^{\text {XLVIII }}$

\subsection{Budget Bill Rules}

Lastly, we take a closer look at States' rules that became directly entangled with budget bills. It is worth noting that generally States adopted the institutional choice of budget proceedings in which the executive branch covers the central role - only in three States can the Governors' budget be fully subverted by the legislatures-. ${ }^{\text {XLIx }}$ While the powers of legislatures to modify the budgets vary significantly, there are also differences in respect to executive powers in budget proceedings. This helps to explain why major constraints on procedural grounds regulate the powers of executives and legislatives, and the balance 
between them. It is possible to group them in three main categories: (1) the most widespread powers regulate the role of the Governor in starting the budget process and in manipulating the items provided therein; ${ }^{\mathrm{L}}$ (2) limits on legislative modifications of the proposed bill; ${ }^{\mathrm{LI}}$ and (3) qualified majority approval to enact the budget, or approve specific items in it. ${ }^{\text {LII }}$ The other procedural rules category concerns the timeline of the budget, with less than half of the States providing a biennial one (see National Conference of State Legislatures 2010: 3). This shows two critical points: on the one side only three States consider two years as a base for consolidated expenditure, on the other no modification in control and management practices has been registered in the shift to a biennial budget (see Musso, Graddy and Bravo Grizard 2009: 260-263).

Looking at substantial rules for budget bills, it quickly becomes evident that it is difficult to determine how they may best be characterized, considering both the lack of clarity and the depth of differences between the provisions of constitutional texts. However, four major types of constraints can be identified. (1) The Governor must propose a balanced budget to the legislature, ${ }^{\text {LIII }}$ although this kind of provision could be weakened if the legislature itself is under no obligation to pass a balanced budget, or if it is possible for the budget to be balanced using borrowing (National Conference of State Legislatures 2010: 6-8). (2) Forty-one States require their legislature to pass a balanced budget. $^{\text {LIV }}$ The main problem with this kind of constraint is the lack of any proper enforcement mechanism. In several cases this balance is considered achieved through the use of estimated expenditures and revenues, and not to fiscal year-end results. ${ }^{\mathrm{LV}}$ (3) This helps to explain why some State Constitutions also provide controls designed to keep the budget balanced throughout the fiscal year, as in the case of Louisiana. ${ }^{\text {LVI }}$ (4) Lastly, some State Constitutions explicitly prohibit the carrying over of deficits, a technique that is often used to achieve a balanced budget in annual systems (National Conference of State Legislatures 2010: 3). ${ }^{\text {LVII }}$

There are several factors that can play a role in determining the effectiveness of budget constraints. One concerns the sources of fiscal limits: while all but one of the States require a balanced budget, only thirty-six do so at the constitutional level, while for the others there are only statutory provisions (National Conference of State Legislatures 2010: 3). In many cases, constitutional limitations have resulted from interpretations of State Constitutions by the States' Supreme Courts, often on the basis of very broad provisions, 
like that in New Hampshire requiring that the State Government act with "frugality." There is also no real correlation between constitutional provisions requiring a balanced budget and those providing debt limits. Enforcement of constitutional provisions requiring a balanced budget also varied greatly, with some limiting only long-term debt and thus allowing an annual deficit, and others allowing some borrowing activity to pay expenditures (see Briffault 1996: 7-9).

Another weakness of the constraints lay in the ambiguity as to what constitutes a budget for this purpose. As mentioned, as a consequence of efforts to circumvent debt limits, State financing was generally divided between a general fund and a number of special, dedicated capital and special trust funds. This meant that the larger part of States' activities lay outside procedures of management tied to the general fund approval process, and there is no evidence that this division reflected that between current and capital expenditures, with the latter generally considered financeable by deficits (see Briffault 1996: 11-14; U.S. General Accounting Office 1995: 3). It is not always clear from the text of budget balancing requirements alone when these requirements applied to specific as well as to general funds, and often the question would simply be remitted to the judgment of the State's accounting offices. Moreover, while according to some studies it is possible to estimate in about three-quarters the percentage of the State budget covered by these constraints (National Association of State Budget Officers 2008: 1), generally the required balance has only a formal nature, with allowance made for the inclusion of funds gained by borrowing activity as revenues in these special funds categories (Eucalitto 2013: 201, and Luppino-Esposito 2014). ${ }^{\text {LVIII }}$

The analysis of financial policies of States confirms that they took advantage of these weaknesses to create various ways to circumvent budgetary constraints. The least sophisticated of these was the use in proposed budgets of optimistic expectations of revenues and expenses (Wolman and Peterson 1981). Another method was timeline alteration: allocating anticipated revenues or shifting expenditures to following years, as well as making use of accrual rather than cash accounting methods so that some expenses would occur in a later year than the revenues with which they would otherwise be tied (see Wolman and Peterson 1981), or the postponement of payments of salaries or for services received by the government (see U.S. General Accounting Office 1995: 72, McCall 1996: 11, and Wallin 1995: 256). A more complicated method of deferring expenses is the 
postponement or underfinancing of pension plan liabilities: in this case the individual rights find, in fact, requirements for a tougher guarantees. ${ }^{\text {LIX }}$

States also made use of certain accounting tricks to achieve balanced budgets. One involved including in the budget expected earnings from the sale of particular assets: these estimated items have been revealed to be tricky both in the sense that they did not rely upon an estimated and credible perspective of assets for sale, and because they achieved a balance between una tantum revenues and recurrent expenditures (see McCall 1996: 17). Another widely-used stratagem was in accounting for a net gain achieved by an extension of debt, through the substitution of higher short-term interest rates with lower long-term ones, which improved the annual budget's ratio of income to expenses, but which increases the State's overall indebtedness. Lastly, States can use weaknesses in areas of the budget covered by those provisions to balance the budget with debt created in systems in which there is, in theory, a borrowing prohibition: they consider as positive items inter-fund transfers, so they can achieve, as an example, a positive item by a transfer from a special district that was financed by borrowing activity (McCall 1996: 27-28, U.S. General Accounting Office 1995: 64).

In the last decades, the impact of intergovernmental transfers on States' budgetary systems has grown to the point that the manipulation of these funds has become a major way to circumvent constitutional budgetary constraints. This happens through combining a reduction in expenditure achieved through spending cuts transferred to local governments, and an increase in funds gained from the federal level. In the first case, local finances have no guarantees in constitutions - except for some acknowledgments in respect of the education sector - and so it is possible to achieve the goal of a balanced budget through cuts in funds given to them. ${ }^{\mathrm{LX}}$ In this case, the effects of the constraints are transferred to local taxpayers, who see an increase in local taxation, which compensates for the loss in transfers. In the second case, the States adapt their expenditure items in such a way as to shift them inside federal programs - especially matching ones which could also give an increase in the transfer received - so reducing the costs for them in their budget (see Briffault 1996: 27-30). 


\section{The Influence of Constraints on Budget Policies of States Facing Fiscal Crisis}

The analysis presented above provides several reasons to doubt the effectiveness of financial constraints adopted by States. In this section the article examines the role played by these norms in determining the policies adopted by three of the largest States California, New York and Illinois - that faced financial troubles during the crisis. Each State studied offers an overview of their budget structure, main problems in managing it and, particularly, the reaction to the financial crisis in 2008. The analysis shows the similarity between budgetary difficulties faced by the States, but also shows how none of the different rules adopted have been instrumental in determining sound budgetary policies, and moreover have had severe effects in other sectors.

\subsection{California}

In the case of California, the budgetary issues include the use of borrowing to achieve a balanced budget, the unfunded liabilities of the retirement system, the increasing costs of Medicaid expenditures, and the volatility of the State's tax structure, which is focused on capital gains as well as income taxes. ${ }^{\mathrm{LXI}}$ The state budget of California generally reveals a structural insufficiency of the State's revenues to finance all of its principal obligations. Seventy percent of the State's spending is focused on two items of about the same relevance: Health and Human Services, and Education (including Higher Education). Other large expense categories include the corrections system, transportation, housing, environmental resources and funding for the functioning of the legislative, executive, and judiciary branches of the State Government. ${ }^{\text {LXII }}$ The criteria for the calculation of such items is a historical one, called "work load", that is based on the amount of money expended in the prior year and makes some adjustment related to political goals. This tends to have the effect of freezing a large amount of expenditure and restricting political debate on budget issues to a very restricted domain. ${ }^{\text {LXII }}$

California has used several instruments to bridge the budget gap that, in the present crisis that began in 2007 , have been focused on temporary measures and not on a revision of levels of expenditures and tax revenues. Federal funds obtained as a result of the American Recovery and Reinvestment Act were used to maintain the level of services 
provided in the two biggest sectors, Health, and Education. The legislature made use of certain forms of temporary tax increases, mainly focused on sales and personal income tax. The State took recourse to accounting stratagem to balance its budget, mainly the deferral of spending obligations and contracting loans. ${ }^{\text {LXIV }}$ In the 2012-13 budget, for example, the measures amounted to about $\$ 28$ billion, of which only $\$ 4$ billion was supplied directly by loans contracted with the direct coverage of the General Fund. ${ }^{\text {LXV }}$ Such forms of budget deferral, combined with the use of overly optimistic previsions about economic growth, create a situation of continuing operating deficits and the absence of corrective action. ${ }^{\text {LXVI }}$

What is distinctive to California's system is the role played by direct modifications of the State's financial constitution by voters. The first initiative of this kind was Proposition 13, approved by voters in 1978. ${ }^{\text {LXVII }}$ This initiative capped both the rate of local property tax related to the value of the property, and any increases in assessed values linked to the rate of inflation. To prevent any state tax increase to compensate for this limitation, Proposition 13 also required the approval of two-thirds of the State Legislature for tax increases. The main consequence of this reform was to shift several public services from local to state funding, in particular the public school system. The limitation on education funding that Proposition 13 entailed led to the approval of Proposition 98, ${ }^{\mathrm{LXVIII}}$ intended to increase spending on specific sectors, fixing a minimum level of State revenues and property taxes dedicated to them. However, the measure did not really work, considering that its very nature - a ceiling or a floor - remains subject to question. The same proposition prescribed that the annual budget includes a "prudent reserve", a provision not effectively binding, given the absence of a definition of 'prudent'. The introduction of a stronger reserve requirement was the object of California Proposition 58 in 2004, ${ }^{\text {LXIX }}$ which required that 3\% of General Fund revenue be transferred each year to a special reserve account called a BSA until the value of this account reached indicated targets. Here, the ease with which the Governor can suspend these transfers in times of fiscal emergency presents a problem. In fact, the trend has been to consider each economic downturn, even small ones, as legitimating such suspensions. Thus, in recent times, the legislature has had to intervene in two directions: increasing the amount of reserves in the BSA that trigger the automatic cessation of transfers, and prescribing the use of unexpected revenues to finance it. $^{\mathrm{LXX}}$ 
In respect of the ways in which constraints influenced budgetary choices, certain points are worth remarking. As mentioned, the passage of Proposition 13 had particular consequences for the state's educational system. American public schools are financed by a combination of local property taxes and state funding. Given the limits introduced by Proposition 13 on local property taxes, the effect was to change the balance between the two sources, increasing the percentage of the state contribution. The sums required were first obtained by a combination of an increase in the general item of Education in the budget, but with a decrease in the share allocated to Higher Education. Proposition 98, approved in 1988, stopped this second element, resulting in an increase in the contribution provided by the State to education, that is one of the biggest, - in terms of percentage among the States, amounting to about $57 \%$ - with local and federal shares amounting to about $30 \%$ and $13 \%$ respectively. ${ }^{\text {LXXI }}$

The influence of a reliance on intergovernmental fiscal measures has been particularly evident for Health expenditure. Being one of the States that provides a more generous eligibility criteria for access to the system of Medicaid - thorough the California Medical Assistance Program -, this was one of the main items that the Governor tried to reduce in times of fiscal troubles. But the combination of federal lack of approval - following successful legal challenges - and the expansive policies of assistance provided at federal level made these cuts to the Health provisions quite ineffective. ${ }^{\text {LXXII }}$

The debt situation is another significant element in the California case. As in other States, debt exposure seems quite irrelevant if measured, taking as reference, $\%$ of personal incomes or \%GDP - especially if compared to States that are dealing with financial troubles in other contexts, such as those in the Europe. But these measurements are misleading: they do not take into consideration the different roles played in the economic and intergovernmental context by the States in the U.S. compared to those other systems. When the very restricted taxation and expenditure as a percentage of GDP of U.S. States is taken into consideration, a proper evaluation of debt exposure must consider other factors as a reference. This could help to explain why California, notwithstanding a debt at about $20 \%$ of GDP, ${ }^{\text {LXXII }}$ has incurred numerous financial problems. Considering that one of the peculiarities of California's budget is the concentration of debt financed as general obligation bonds, or supported in some way by the general fund, ${ }^{\text {LXXIV }}$ it becomes clear that the connection between revenues and debt service costs becomes the key data in 
understanding the budgetary behaviour of the State: in the proper State estimates until 2020 over $8 \%$ of the revenue must be used to cover this kind of expenditure. ${ }^{\mathrm{LXXV}}$ Moreover, California presents also a problem of short term debt, typical in a system in which in the general fund, revenues are collected at the end of the fiscal year, while expenditure must be financed for short term purposes. In this situation, the State uses both external and internal borrowings to cover these costs. The first are typically Revenue Anticipation Notes, that formally are not considered as debt in the constraint view because they are payable before the end of the same year of emission. The internal borrowings are, instead, examples of the use of inter funds manipulation to hide budget troubles: the State meets the expenditure costs with a loan from the special funds. After the crisis that involved California in 2009, the State was also forced to issue a series of promissory notes, or IOUs, as a way to delay payments and maintain general fund expenditures. ${ }^{\text {LXXVI }}$

Budgetary difficulties forced the State to adopt - beginning in 2010 - a number of modifications to the legislative framework of the process. These reforms focused on procedural requirements: the majority required for approval of the budget was modified from two-thirds to a simple majority. ${ }^{\text {LXXVII }}$ Other reforms focused on manipulation of the timeline of the budgetary process, particularly on the timeline of the calculations and on the time coincidence between items. ${ }^{\text {LXXVIII }}$ Moreover, reforms also impacted on fiscal policy, with the approval of Proposition 30 that temporarily increased personal income and sales tax. ${ }^{\text {LXxix }}$ The effect of the last provision in particular was to strengthen the budgetary status of the State. In any case, several analysts have noted that the temporary nature of the increase of revenue in Proposition 30 is a risk for the evolution of California's budget. ${ }^{\text {LXxx }}$

\subsection{New York}

To understand the budgetary policies of New York State, certain specificities must be noted. In the last fifty years the State has been characterized by a progressive separation between the economically and demographically growing New York City area, and the rest of the state, which registered a decline in its economic situation connected to the crisis in manufacturing industry. Within this general trend, the crisis of 2008 particularly affected the State's budgetary situation. Naturally, the Wall Street crisis particularly affected the State of New York, resulting in a loss of jobs greater than the national median. ${ }^{\text {LXxxI }}$ The State's budget, strongly connected to the financial revenue of the City, registered a deficit, 
worsened by efforts to enact temporary policies to cushion the impact of the crisis. The first measure to meet the budgetary troubles was a modification that tried to limit spending growth. This was effected through two-year, instead of the classic annual, appropriations for education aid and Medicaid expenditures and through the introduction of new tools to check and monitor spending and balances. Moreover, an annual cap was applied to any increase of expenditures for the two biggest items of the state budget, defined by external parameters. Lastly, the executive was empowered with the facility to reduce Medicaid spending during the fiscal year. ${ }^{\text {LXXXII }}$

The New York system is noteworthy for two elements that have made it one of the States in which many of the accounting tricks mentioned before were developed (see as an example Ravitch 2010). One was the choice to use as a parameter a cash budget, while the GAAP (Generally Accepted Accounting Principles) criteria were used only for reports. The other was that, after the Budget Reform Act of 2007, only the general fund budget in New York has to be balanced. ${ }^{\text {LXxIII }}$ Effectively, as the general fund covers less than half of the total budget of the State, no such kind of balancing provision was provided for the overall exercise. Moreover, there was also no requirement for the budget, once approved, to remain balanced throughout the fiscal year, and this opens the door to practices such as timeline manipulations or overestimation. Finally, the requirements of general fund balances, where extended into an evaluation of a multi-annual framework, are only contained in the Budget Reform Act, a merely statutory requirement that could be easily circumvented by the approval of subsequent legislation. ${ }^{\text {LXxxiv }}$

In the fiscal behaviour of New York State a central issue to analyse is the constitutional fiscal framework. Article VII of the Constitution is totally dedicated to State finances. In this context, the powers of the Governor are particularly interesting. The budget procedure is, in fact, characterized by the strong role of the executive in the formulation, presentation and execution phases of the budget. To enforce these kind of rules there are exclusive powers provided for the Governor in the submission of items concerning the expenditure of the executive branch. Moreover, once presented he possesses a veto power, albeit not absolute, on items modified by the legislature, and can also modify some items approved in the executive phase. ${ }^{\mathrm{Lxxxv}}$ So it is clear why, in this kind of system, the boundaries for a balanced budget concern, first of all, the Governor himself. The legislature affords several limits in the matter of budget choices. In a general way, the power that it possesses is 
concentrated on the negative side, in terms of the possibility of reducing the authority for spending or reducing proposed appropriations made by the Executive. However, in the positive direction, the legislature finds it impossible to substitute items proposed by the Governor or significantly modify the proposed appropriations. ${ }^{\text {LXXXVI }}$ As a consequence the system is structured in a way that makes it clear that policy budgetary choices are part of the Governor's tools.

The New York Supreme Court, in Potaki v. New York State Assembly, rigorously evaluated such an understanding, clarifying different elements. It identified the scope of constitutional mutation in the alteration of the roles of executive and legislative in the budget process: the first must be considered the "constructor" of the budget, while the second has a "critical" role, in which approval is needed. ${ }^{\text {LXXXVII }}$ Moreover, executive powers have also been extended with two considerations concerning the possibility to challenge the budget contents. Firstly distinctions between appropriation and policy are now considered non-existent, thus expanding the political doctrine perimeter. Secondly, there is no legal constraint that could be judicially enforced on the Governor that might prevent him from inserting substantive law changes in the budget bill. These elements have been combined with the exclusion of the amendment power of the legislative both regarding the budget bill and the policy conditions connected. This kind of instrument could modify the balance of power provided for in the N.Y. Constitution, which sought that the executive might not provide a "rival constructor" role to the legislative branch. ${ }^{\text {LXXXVIII }}$ The effect of the procedural budgetary framework, combined with this interpretative approach, deeply influences the balance of power. The legislative power has no choice as to whether to approve or, through a refusal to act, to force an impasse with potentially devastating effects. As a consequence, the executive powers were broadly extended, including the ability to make policies beyond the budget, ${ }^{\text {LXxxIx }}$ while the ability of the legislative to check the executive compliance to constraints has been severely eroded.

The use of accounting devices has been confirmed in the recent fiscal troubles: the primary way in which the Governor achieved a balanced budget was through cash manipulation, in particular through delaying payments to subsequent years. When the legislature blocked such moves, the only way to submit to the requirement was to make repeated use of temporary loans allowed for by the constitution. ${ }^{\mathrm{XC}}$ Moreover, this kind of policy received a positive evaluation from the New York Courts. In Wein v. Carey, the 
issue was about a short-term debt contracted to cover a year-end deficit. This case is particularly effective in demonstrating the misleading use of the legislature framework regarding States' budgetary constraints: the conclusion of the judgement was that the budget was not unbalanced even if there were successive years of unpredictable shortfalls that would force the use of short-term debt. ${ }^{\mathrm{XCI}}$ As a consequence, a nominally balanced budget - achieved through borrowing - can be successfully challenged only in the case of a planned shortfall, or a deliberate alteration of fiscal estimates (in this direction, see Briffault 2009: 428-429).

Let me summarize some points helpful for this research. In the New York case, the difficulties resulting from the economic crisis were combined with a structural deficit imbalance in the state budget. The revenues were both inadequate to fund the spending indicated, and they increased at a slower rate than the latter. The formal balance was achieved through a combination of accounting devices: transfers from other authorities, delays in payments, and manipulating existing debts and assets. This element, combined with the annual need for a balanced budget, created a trend in which the budget would be balanced by the year's end, while projections for the following year continued to worsen. As in the general reconstruction mentioned the constitutional framework encouraged the use of such stratagem: providing a constraint only for the general fund creates a strong incentive for the creation of a broad system of special funds. As a result, the manipulation of funds became widespread as a reaction to the fiscal troubles connected to the crisis. ${ }^{\mathrm{XCII}}$

\subsection{Illinois}

The last of the case studies is selected to analyse the ways in which a State can operate under a budget that is fiscally unsustainable. Illinois is ranked in the lower half of States in several areas involving fiscal conditions, particularly with regard to bond ratings, unfunded pension liabilities, and unpaid bills (Topinka 2012). The reasons are not connected to any particular weakness in the economy of the state, but at the beginning of the crisis, it found itself in a position of both budgetary and political weakness. In fact, the State's budget had no reserve and had made a massive use of accounting devices and borrowings in previous years. ${ }^{\text {XCII }}$ Moreover, one Governor found himself subject to federal investigations and his successor in difficult relationships with the legislature. So, in Illinois quite soon the 
economic crisis became the "perfect storm" of financial difficulties, in a situation in which each one of the theoretical budgetary problems for a State were present concurrently.

The University of Illinois' Institute of Government summarized the main features of this financial crisis in a report covering the fiscal years 2011-13. ${ }^{\mathrm{XCIV}}$ In this research, for the 2011 budget the estimated deficit, which used a form of consolidated budget, was about $\$ 11$ billion dollars plus $\$ 6$ billion carried over from prior years. The impact of this sum on the State budget was modelled in a dramatization using a hypothesis of measures that would be able to resolve the situation, such as collecting all income, sales, and consumption tax for the next five years. The Legislature reacted by temporarily increasing corporate and personal income tax and by capping General Fund expenditure. ${ }^{\mathrm{XCV}}$ The projections of such measures on the following years predicted a persistent deficit situation, forcing the legislature to enact several stabilization reforms in the following years. Although the budgetary situation became more sustainable, two problems remain unresolved in the fiscal policy: the costs of pensions, and Medicaid, which were crowding out the rest of the budget, and the deficiencies of the budget process. ${ }^{\mathrm{XCVI}}$

Two primary factors emerge when we examine the politics that lead the State to its situation of weakness. The balance of the annual cash budget had been obtained several times by avoiding putting aside all the required sums for future pension benefits - thus also increasing unfunded liabilities - and by policies of expenditure growth in good economic times, practiced without raising taxes or putting away cash reserves - thus creating a structural deficit -. ${ }^{\mathrm{XCVII}} \mathrm{In}$ the second element in particular, a key role was played by conflicts between the Governor's programs to increase state services and the legislature that fiercely opposed, until 2011 at least, any kind of tax increase. This is particularly germane to this research; this budgetary behaviour is connected to the lack of electoral support for fair budget policy. Illinois is considered a fragmented political state, with very different economic interests between the city of Chicago and the remaining part of the State, and also with the main town classically democratic and the southern part more devoted to the Republican Party. This situation explains why it has been so difficult to create proper budgetary politics, with a balanced system of expenditures and revenues, given that different parts of the State were pushing for totally different politics. Electoral support plays a key role in the effectiveness of budgetary constraints, and the Illinois case could be a convincing example in support of this theory. 
Looking at the institutional framework, a first element to be noted is that the offices of the Governor play a key role in the budget formation procedure. The contents of the budget are determined by the cooperation between the Governor - fixing the budgetary objectives and directives for state agencies - and the Governor's Office of Management and Budget (GOMB) - that both collect the expenditure requirements from the agencies and make estimates for the fiscal exigencies required to accomplish the goals determined. This process, built into the executive branch of the government, allows only a few actors to play a strong role in determining budgetary decisions. The legislature only has the power to vote on the final budget proposed, usually within a timeframe that makes a deep analysis of the budget difficult to achieve (see Nowlan, Gore and Winkel 2010: 215).

One of the interesting points for this research, is that this situation of budgetary troubles has been created in a system in which the constitution requires that "the proposed expenditure shall not exceed the funds estimated to be available" for the budget year in question. ${ }^{\mathrm{XCVIII}}$ The weakness of this constraint is connected to the possibility of adopting temporary accounting devices and in creating unrealistic estimates of available funds. Moreover, also in the case of Illinois, the budget is a cash annual concept, which excludes accruals. These factors explain why the government has been able to achieve the required balance by postponing payments for pension benefits, so creating the massive amount of unfunded liabilities still present. The institutional weakness of the budget helps to explain the huge number of unpaid bills registered; considering that they are not considered in a cash budget as negative items, as avoiding or delaying payment could be a way to achieve the required balance. ${ }^{\text {XcIx }}$

The budgetary devices that contributed to the financial troubles of Illinois included timeline and funds manipulation, and misleading information and planning. The more influential practice of timeline shifting was registered in pension obligation bonds. As mentioned before, the government also broadly implemented payment delay practices. Funds manipulation, on the other hand, exploited the composition of the Illinois budget: with the general fund covering only half of expenditure, one of the more common ways to achieve the required balance was to shift unbalanced items to special funds not considered as being in the constraint mechanism. Moreover, special funds were also exploited to create revenue: through sweeps and chargebacks, the government could take back, in the case of positive operating results, profits from special funds to finance general operations, through 
inter-fund borrowing or transfers, although this kind of operation, when challenged in the judiciary, did receive the approval of the Illinois Supreme Court (Wetterich 2011). Lastly, Illinois lacked two key elements that are considered central to assuring the financial stability of a State: a provision for multi-annual budgetary planning, and a duty to form reserves as rainy day funds. ${ }^{\mathrm{C}}$

The crisis partially modified this situation. As a first step, the legislature decided to force the Governor to make cuts by financing appropriation in lump sum amounts for the federal agencies. In 2012, where normal proceedings were resumed, the Governor introduced detailed controls in respect of the predetermined expenditure by the agencies and started to release official three-year projections of the General Fund budget. ${ }^{\mathrm{CI}}$ This confirms that also in this latter case, the institutional weakness has been perceived as a cause of the financial distress.

\section{The interpretative approach of Courts}

The data of deficit budgetary policies of these States require us to seriously question the extent to which constraints proved legally binding. By looking at both the general analysis and the case studies, we can see how States have been able to reduce the effectiveness of constraints through their evaluation in a restrictive interpretation. This behaviour has been possible for two reasons: one is the weakness of the rules as discussed earlier, and the other is the permissive position assumed by States' Supreme Courts. According to Briffault (see Briffault 2003: 939-949), it is possible to individuate some common motivations among the courts for this interpretative trend, which regards these provisions as a "disfavoured Constitution".

The first is that courts consider that financial constraints have more similarity with ordinary legislation than with matters concerning fundamental rights or government structure. This approach explains why different courts, when looking at these rules, make the point that, without the involvement of any individual right, questions concerning them are best solved by elected representatives, ${ }^{\mathrm{CII}}$ and that the courts must adopt a deferential approach to the legislature that has the responsibility of adopting States' fiscal policy. ${ }^{\text {CII }}$ These interpretative trends show some similarities with the deferential approach taken by the U.S. Supreme Court after the New Deal, but within a completely different framework: 
while the Federal Constitution is almost silent on fiscal elements, the States' courts must downgrade several parts of their constitutional texts into mere technical norms and circumvent them to achieve the same goal.

This leads us to a second element: the courts, perhaps considering the elective nature of their appointment, ${ }^{\mathrm{CIV}}$ adopt in the formulation of their judgements an approach that explicitly shares the policy goals of their governments. The broad interpretation of the clause of public purpose testified to this trend: considering that almost every kind of public expenditure could increase the economic growth of the State by being an expansive policy, the courts shared the same motivation that politicians had in disabling the clause. ${ }^{\mathrm{CV}}$ Moreover, when looking at debt limits, several courts had explicitly seen the deficitfinanced activities as a public interest to be promoted, so they considered the extensive use of accounting devices as discussed as a means to guarantee necessary flexibility for their governments. ${ }^{\text {CVI }}$ It seems clear that a similar approach, evaluating purpose against constitutional rules, is a key element in explaining the ineffectiveness of the debt limits illustrated above. ${ }^{\text {CVII }}$ This approach to the rules could also be connected to two other elements that could help explain the adoption of a more stringent one when looking at taxation rules. One factor is the absence of a right directly affected by the violation of the constraints, where in taxation rules, it is easier to find a subject that has had a direct loss connected to an increase. The other factor may be that the TELs rules are quite recent, while the other constraints are generally old and this could explain the consideration that in one case they reflect a value, and continue to have support, while in the other this element could be questioned or not considered.

\section{Conclusions}

Our research has focused on the dynamics between fiscal institutional rules and their effect on policy. Trying to summarize the points, while it is possible to argue some kind of positive effect in respect of financing costs (Poterba and Rueben 1999) a question arose concerning the effectiveness of the constraints. This article has tried to demonstrate that all institutional tools present legal weaknesses that created the grounds for the adoption of circumventing techniques. This point, firstly assessed in a general analysis, was stressed through looking at the behaviour of some States that faced very similar budgetary troubles, 
notwithstanding differences in their budgetary constraints. Several studies have demonstrated that, by looking deeper than a general balanced budget provision, differences can be seen between the behaviour of States, for example, in terms of timelines of budget, or ways of nominating the Supreme Court judges, or conditions for borrowing (see Bohn and Inman 1996: 13-76; Mahdavi and Westerlund 2011). But each kind of constraint seems to be unable to reach the goal of a sound budgetary policy, while differences emerged in terms of what kind of institutional effect and influence on the contents of budget they can determine. The overall effectiveness of constraints to impose balanced budget policies can be called into question: fiscal excesses are simply manifested in off-budget forms (Greve 2012: 20). This leads us to an analysis of another factor that helps to explain the legal weakness of the constraints, the interpretative approach of courts. As shown before, the deferential approach of the judiciary strongly contributes to the erosion of the binding nature of requirements.

We have seen that the weakness of the constraints allows for the adoption of different means to circumvent them, and so achieve a formal policy of imbalanced budget. But, in some States, and in some constraints this does not happen: the constraints are instead respected. The analysis of these constraints shows that the institutional framework works with other factors in determining the fiscal behaviour of States. The study evidenced three other elements that strongly influence budgetary behaviour. (1) The economic cycle. While there are, at the federal level, several ways of minimizing the impact of this on the budget, at the state level both the composition of expenditure and revenues, and the scope of the budget in respect to the economy make the government's financial behaviour more receptive to economic boom and crisis. ${ }^{\text {CVIII }}$ (2) The political support for a determined budget policy. It is possible to affirm that the endogenous support for a determined budgetary policy can both push for the adoption of a constraint and strengthen the binding nature of the same: it increases the costs - electoral ones - of political circumvention and leads to stricter scrutiny by the courts. ${ }^{\text {CIX }}$ Moreover, the element of political support connected to budgetary constraints may be considered as the main effect of a conflict between bond holders and taxpayers: while the first are generally interested in a balanced politics in order to guarantee their credit, the interest of the second can vary. Governments generally, looking to electoral support, tend to support the interests of taxpayers, and so their fiscal behaviour may or may not be "responsible" as a consequence of political 
support (see Schragger 2012: 885-886). ${ }^{\text {CX }}$ (3) The research seems to lead to the conclusion that federal intervention is one of the main elements that gives stability to the system: constant policies, implicit bailouts, and counter-cyclical programs partially absorbed the troubles of States, moreover they give them the financial space to follow voters' favoured budgetary politics (in this direction see also Henning and Kessler 2012: 14-15).

This article has shown that the effectiveness of fiscal rules can be questioned on several grounds. However, these rules exist and, whilst ineffective, their presence is not without consequences. It is possible to summarize some distortive effects connected to them. The main effect is connected to the behaviour of States between economic cycles: reflecting a negative vision of deficit spending and debt, constraints that seriously undermined the ability of States to take counter-cyclical policies and had, instead, pro-cyclical effects. The other distortions are connected to the tools used by States to circumvent constraints. Each kind of constraint caused a modification in the budget composition; the balanced budget requirement generated incentives to leave off costs and activities, to underfund long-term commitments, and to move costs between years. Tax limitations - focused on property tax - created an incentive for the growth of sales and capital gains taxes and a system in which States and local governments rely heavily on fees and intergovernmental transfers to gain sufficient revenues. Alongside this, there was an increase in the use of special districts or authorities to circumvent both the tax-increment limits and to finance services in deficit. As previously shown, the composition of indebtedness is another element distorted by the combination of the fiscal rules and by the interpretative activities of the courts that "concede" some kind of debt. Moreover, the combination of the commitment assumed through distorted financing mechanisms and the limited autonomy in the revenue sector created an overall restriction of spaces for policies in the budget, restricting the percentage of modifiable items present.

The weakness in the constraints, and the deferential interpretative approach of the courts, erodes the effectiveness of constraints. As a consequence, States' governments have been able to follow their preferred policies without being seriously confined by those provisions. This has been confirmed by the behaviour of administrations throughout the fiscal crisis: more receptive of economical and political exigencies than worried about complying with the requirements. If constraints are not able to autonomously determine sound budgetary policies, they cause, for sure, the creation of a number of adaptive 
techniques. The uses of gimmicks, devices, stratagem and instruments widely illustrated seriously questions the utility of constraints, at least in the weak legally binding version so far analysed, and generate a series of unintended distortions in the budget processes, the balance of power and the outcomes in policy terms.

* PhD Candidate, Scuola Superiore Sant'Anna. I would like to thank Professor Richard Briffault for comments.

I Patient Protection and Affordable Care Act, Pub. L. n. 111 -148, 124 Stat 119, 2010.

II Pub. L. n. 111 - 5, 123 Stat. 115.

III According to Wallis 2002, the problem of tax-less finance played a central role in both this crisis and the efforts to address it. The indebtedness of many states has been analysed in several studies. See, e.g., English 1996; McGrane 1935; Ratchford 1941.

IV The difference is particularly evaluated in Henning and Kessler 2012: 10-11.

v In this directions, see Hou and Smith 2009; Mahdavi and Westerlund 2011.

VI The connection between ways of selection of judges and the degree of enforcement of the budget rules is marked in See Bohn and Inman 1996.

VII Particularly focused on those elements is the analysis of Poterba and Rueben 1999.

VIII This is one of the conclusions on the theme adopted by Briffault 1996: 60. The research of J.E. Alt and R.C. Lowry (Alt and Lowry 1994) is instead focused on the degree of control of the houses by the parties.

IX In their establishment, also economic and political pressures played a role. This is the approach taken, for example, in Rodriguez Tejedo and Wallis 2012.

x According to R. Briffault, (Briffault 2003: 910), forty-six states require such a measure, while the others all have judicial doctrines that provide the same result.

XI According to Ratchford 1941: 105-114, this constraint originally applied only to state governments. The circumvention of these limitations by delegations to local government of debtors made necessary a further expansion of these constraints.

XII This idea is also confirmed in certain court judgements that admitted the use of public funds to finance private railroads, taken into consideration throughout the public interest behind such infrastructures. See Sharpless v. Mayor of Philadelphia, 21 Pa. 147 (1853).

XIII See, as examples, Albritton v. City of Winona, 178 So. 799, 804 (Miss. 1938), State ex rel Beck v. City of York, 82 N.W.2d 269 (Neb. 1957). For a reconstruction of this evolution, see Briffault 2003: 912-915.

XIV The more explicit case in this direction, admitting that a spending will be considered as pursuing the public purpose as long as is it "not irrational" is Delogu v. State, 720 A.2d 1153, 1155 (Me. 1998).

$\mathrm{XV}$ Maybe one of the few effects that those provisions still have is to limit the possibility of state investment in business corporations, on this see Pinsky 1963: 278-79.

XVI See IND. CONST. art. X, $\sqrt{ } 5$, prohibiting state debt except "to meet casual deficits in revenue," repel invasion, suppress insurrection or provide for state defense.

XVII See ARIz. CONST. art. IX, \5 "the aggregate amount of such debts (...) shall never exceed the sum of three hundred and fifty thousand dollars."

XVIII See as an example GA. CONST. art. VII, $\int$ IV, 1 II, limiting debt service on state debt to $10 \%$ of state revenue.

XIX See as an example, N.Y. CONST. art. VIII, \2-a.

$\mathrm{xx}$ See as an example, CAL. CONST. that provides the first for the state in art. XVI, $₫ 1$ and the voters' referendum for other administrations in art. XVI, $\ 18$ "No county, city, (etc.) shall incur any indebtedness or liability in any manner or for any purpose exceeding in any year the income and revenue provided for such year, without the assent of twothirds of the voters of the public entity voting at an election to be held for that purpose".

XXI See as an example, WASH. CONST. art. VIII, $₫ 1$.

XXII AL. CONST. art. X, $\ 213$ "After the ratification of this Constitution, no new debt shall be created against, or incurred by this state (...)".

XXIII To fully evaluate the weakness here exposed it is important to mark that the debt limitations were the main result of a series of reforms implemented after the financial crisis of the 1840 s, with the last constitutional provisions aimed at placing restrictions on debt of this kind adopted at the beginning of the twentieth century. The oldness of these constraints may help to explain certain problems with regard to their 
effectiveness. See Ratchford 1941: 73-104.

xxiv See as an example, Flushing National Bank v. Mun. Assistance Corp., 358 N.E.2d 848 (N.Y. 1976).

$\mathrm{xxv}$ R. Briffault defines this kind of obligation as "non-debt debts", an efficient way to describe the tension between formal consideration and substantial role of those actions, see Briffault 2003: 918 (e Part. III.C.). xxvi See, Okla. Capitol Improvement Auth., 958 P.2d 759 (Okla. 1998); Convention Ctr. Auth. v. Anzai, 890 P.2d 1197 (Haw. 1995).

XxvII See Train Unlimited Corp. v. Iowa Ry. Fin. Auth., 362 N.W.2d 489 (Iowa 1985); Schulz v. State, 639 N.E.2d 1140 (N.Y. 1994); Dykes v. N. Va. Trans. Dist. Comm'n, 411 S.E.2d 1 (Va. 1991).

xxviII See, e.g., Crowder v. Town of Sullivan, 28 N.E. 94 (Ind. 1891); Struble v. Nelson, 15 N.W.2d 101, 104 (Minn. 1944); Bd. of Supervisors of Fairfax Co. v. Massey, 169 S.E.2d 556, 559 (Va. 1969); State ex rel. City of Charleston v. Hall, 441 S.E.2d 386, 389 (W. Va. 1994).

xxix See Bulman v. McCrane, 312 A.2d 857 (N.J. 1973); Dep't of Ecology v. State Fin. Comm., 804 P.2d 1241 (Wash. 1991); Dieck v. Unified Sch. Dist. of Antigo, 477 N.W.2d 613 (Wis. 1991). But see Montano v. Gabaldon, 766 P.2d 1328 (N.M. 1989).

xxx See Carr-Gottstein Props. v. State, 899 P.2d 136 (Alaska 1995); In re Anzai, 936 P.2d 637 (Haw. 1997); Wilson v. Ky. Transp. Cabinet, 884 S.W.2d 641 (Ky. 1994); Employers Ins. Co. of Nev. v. State Bd. Of Exam'rs, 21 P.3d 628 (Nev. 2001); Schulz v. State, 639 N.E.2d 1140 (N.Y. 1994); Fent v. Okla. Capitol Improvement Auth., 984 P.2d 200 (Okla. 1999); Dykes v. N. Va. Transp. Dist. Comm'n, 411 S.E.2d I (Va. 1991).

xxxi See for example Rider v. City of San Diego, 959 P.2d 347, 358 (Cal. 1998).

xxxiI Lonegan v. State, 809 A.2d 91 (N.J. 2002). However, in a following judgment - take by a simple majority of the judges - the same court saved similar measures looking to the absence of any legal enforceability of them against the state, see Lonegan II, 819 A.2d 395 (N.J. 2002).

xxxiI See MICH. CONST. art. IX, $\int 8$ (capping the sales tax rate).

xxxiv See FLA. CONST. art. V, \5 (prohibiting personal income tax); MICH. CONST. art. IX $\int 7$ (prohibiting graduated income tax); N.C. CONST. art. V \6 (limiting income tax); TEX. CONST. art. VIII, $\int$ 9 (prohibiting personal income tax without voter approval).

xxxv See CAL. CONST. art. XIIIA, $\ 3$ (requiring state legislative supermajorities in order to increase state taxes); id. art. XIIID (making voter approval a requirement for all tax increases); DEL. CONST. art. VIII, $\int$ 10, 11 (requiring legislative supermajorities for imposing or increasing a tax or a fee); MICH. CONST. art. IX, $\int 25$ (requiring voter approval as condition for new or increased state or local taxes); Mo. CONST. art. X, \S 18, 22 (setting tax limits and conditioning new or increased taxes and fees on voter approval); S.D. CONST. art. XI, $\iint 13,14$ (requiring either legislative supermajority or voter approval in order to increase state taxes or the property tax).

xxxvi See ARIZ. CONST. art. IX \ 18; CAL. CONST. art. XIIIA, \2; FLA. CONST. art. VII, \9; LA. CONST. art. VI, \6; MO. CONST. art. X, $\int 11 ;$ NEB. CONST. art. VIII, $\int 5 ;$ NEV. CONST. art. X, $\int 2$; N.Y. CONST. art. VIII, \10; OHIO CONST. art. XII, \2; WASH. CONST. art. VII, \2; W. VA. CONST.

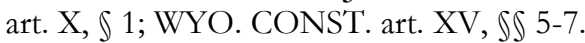

xxxvII See ARIZ. CONST. art. IX, \ 19; CAL. CONST. art. XIIIA, \2; FLA. CONST. art. VII, \4; LA. CONST. art. VI, \ 3; MICH. CONST. art. IX, $\ 3$; OKLA. CONST. art. IX, $\int 8 B ;$ OR. CONST. art. XI, $\int$ 1l(1)(b).

xxxVIII See ARIZ. CONST. art. IX, $₫ 17$.

XXXIX See ARIZ. CONST. art. IX, \22; CAL. CONST. arts. XIIIA, XIIIC, XIIID; COLO. CONST. art. X, $₫$ 20; 11; GA. CONST. art. VIII, \ 6, 11; HAW. CONST. art. VII, \9; LA. CONST. art. VI, \25; id. art. VII, \ 2; MICH. CONST. art. IX, $₫ 25 ;$ MO. CONST. art. X, $\int \ 18,22 ;$ S.C. CONST. art. X, $\int 7$.

$\mathrm{XL}$ We will specific evaluate this provision in our case study about California in section III.i).

XLI For a complete reconstruction, see Skidmore 1999: 77, 83, and 88.

XLII MICH. CONST. art. IX, \S 25-32.

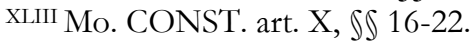

XLIV See, as examples, ALASKA CONST. art. IX $\int 16$ (connecting increases in state appropriation to population growth and inflation) and S.C. CONST: art. X $\int 7$ (providing a limit in state spending that could be changed only by two-thirds legislative vote). For a dissertation on those constraints, see Briffault 2003: 929-932. 
XLV See for example the position of the California Supreme Court about limitations of other taxes as special and the consideration of the special districts, City \& County of San Francisco v. Farrell, 648 P.2d 935 (Cal. 1982); L.A. County Transp. Comm'n v. Richmond, 643 P.2d 941, 947 (Cal. 1982).

XLVI See for examples, McNally v. Township of Teaneck, 379 A.2d 446, 451 (N.J. 1977) (finding a special assessment not a tax subject to certain constitutional requirements because the purpose of the assessment was to reimburse the municipality for its expenditure); Lakewood Park Cemetery Ass'n v. Metro. St. Louis Sewer Dist., 530 S.W.2d 240, 245-46 (Mo. 1975) (finding that charitable property constitutionally exempt from taxation may be required to pay a special assessment): Briffault 2003: 934-935.

XLVII See for example Knox, 841 P.2d at 151 (allowing special assessment for parks); City of Boca Raton v. State, 595 So. 2d 25 (Fla. 1992); 2d Roc-Jersey Assocs. v. Town of Morristown, 731 A.2d I (N.J. 1999) (allowing assessment for business improvement district).

XLVIII Particularly clear about the effects of such kinds of circumventing techniques has been the Supreme Court of Michigan, that assessed that "the imposition of mandatory 'user fees' by local units of government has been characterized as one of the most frequent abridgements 'of the spirit, if not the letter,"' of that state's anti-tax amendment. (Bolt, 587 N.W.2d at 273). Also the courts of Missouri and California tried to distinguish and categorize fees, in order to reconduit some of them to the applicability of the tax limit. The case law has been particularly analysed by Briffault 2003: 935-937.

XLIX According to National Conference of State Legislatures 2010, these are Arizona, Colorado and Texas. A similar reconstruction, that focuses on the powers of executive and legislative among the budget procedure, from the initiative to the execution phase is offered in O'Connor 2015: $355-368$.

${ }^{\mathrm{L}}$ In half of the States, the governor initiates the budget approval process. In approximately four-fifths of the States, the governor holds the power to remove items from the budget approved by the legislature, while the power to reduce the amount of single items is far less common: only one-quarter of the States providing it. The great majority of States provide some limits to the modifications that the executive can make after the enactment of a budget, also in terms of reducing budget spending items. See Hou and Smith 2006; U.S. General Accounting Office 1995: 15.

LI As an example, half of the States provide rules to contain supplemental appropriations approved by the legislature on a timeline basis, consenting to them only in the legislative session, see Musso, Graddy and Bravo Grizard 2009: 252-254.

LII A few, mostly north-eastern, States require a supermajority to enact a budget, only three States require a qualified majority to enact the state budget and another six require this majority for votes upon some particular items of it, see data from Council of State Governments 2008. Requirements of a supermajority are much more commonly used to limit tax increases or revenues (thirteen providing it), see Knight 2000.

LIII See for example the Rhode Island Code, Title 35, ch 3, s 13.

LIV National Association of State Budget Officers 2008, and the following reports. See, for example, The Delaware Code, Title 29, ch 63, s 6337.

LV According to Hou and Smith 2006: 34-35, six states have a constitutional requirement and twenty-nine have a statutory requirement to avoid that deficit could be carried to the next fiscal year. They explicitly links the unpopularity of this measures to the fact that it leaves a narrow space for circumvention, Hou and Smith 2006: 42. O'Connor 2015: 359-360 shows that as counter-balance some states provide the admissibility to rebalance the budget among the fiscal year with supplementary appropriation, see See ALA. CONST. art. XI, $\$ 213.

LVI See The Louisiana Code, Title 39, s 72(A).

LVII See as example The Montana Code, Title 17, ch 7, s 131(2).

LVIII Moreover, also in the general fund, generally the States balance only their operating budget; see O’Connor 2015: 356 - 358. The operating budget generally includes expenditures like salaries and wages, aid to local governments, health and welfare benefits, and other annual outlays, while excluding such expenditures as construction and land purchases, see National Conference of State Legislatures 1996.

LIX See for example Musselman v. Governor, 533 NW2d 237, 241 (S.Ct.Mich. 1995).

LX See Michigan Association of Counties v. Department of Management and Budget, 345 NW2d 584, 592 (Mich. 1984).

LXI The state's revenue structure is based on personal income tax source, and contributing to this is a trend in recent decades towards a decreasing use of sales and use taxes. (See California Legislative Analyst's Office, http://www.lao.ca.gov/Budget) An interesting point is that roughly $70 \%$ of these revenues go to the general fund, with the remainder being used to fund special ones. The trend towards an increasing reliance on 
income tax is particularly remarkable, because it can contribute to one of the more problematic issues of a state budget: the behaviour during economic downturns. In fact, the personal income tax revenue amplifies the effect of decrease of revenue in these occasions. This happened to the revenues of California during the crises of 2001 and 2007, in a way that strongly contributed to the state's financial troubles. See The State Budget Crisis Task Force, California Report, 2012 p. 12.

LXI See California Department of Finance, Enacted State Budget 2012-13 Summary, as an example, available at http://www.ebudget.ca.gov/FullBudgetSummary.pdf.

LXIII The "work load" is an example of conventional budgets that have been fiercely criticized for the aforementioned reasons by the scholars. See as examples, Tobin 1996: 155; Williams 2013.

LXIV In 2011, when the governor used \$11 billion of loaned money from bonds to lower the deficit from $\$ 20.6$ billion to $\$ 9.6$ billion (Lusvardi 2011).

LXV See California Department of Finance, Multi-Year General Fund Budget Projection, available at http://www.dof.ca.gov/reports and periodicals/documents/MY Website Workbook 2016-17 GB.pdf.

LXVI See California Department of Finance, Multi-Year General Fund Budget Projection 2012-13.

LXVII Prop. 13, People's Initiative to Limit Property Taxation, 1978.

LXVIII Prop. 98, School Funding. Initiative Constitutional Amendment and Statute, 1988.

LXIX Prop. 58, California Balanced Budget Act, 2004.

Lxx See The State Budget Crisis Task Force, California Report, pp. 13-14.

LXXI See U.S. Department of Education, National Center for Education Statistics, Common Core of Data, available at https://nces.ed.gov/ccd/.

LXxi See The State Budget Crisis Task Force, California Report, pp. 19-20.

LXxiII Source U.S. Census Bureau, State Government Finances Summary Report, at https://www.census.gov/govs/state/.

LXXIV This percentage amounts to about $90 \%$ of the total debt of California, while the other states had a much more significant exposure supported by special funds, see Office of the State Treasurer, State of California Debt Affordability Report, 2011.

LXXv See Office of the State Treasurer, State of California Debt Affordability Report, 2011.

Lxxvi See State of California Revenue Anticipation Note Office Statement, September 2011, available at http://www.sco.ca.gov/files-eo/9-11summary.pdf. California issued in 2009 a peculiar form of these promissory notes, called Registered Warrants, see http://www.sco.ca.gov/eo news registeredwarrants.html. LXXVII California Secretary of State. Official Voter Information Guide. Proposition 25 Analysis by the Legislative Analyst, $\quad$ November $\quad 2010, \quad$ http:// www.voterguide.sos.ca.gov/past/2010/general/propositions/25/analysis.htm.

LXXVIII California Secretary of State. Official Voter Information Guide. Proposition 39 Analysis by the Legislative Analyst, $\quad$ November 2012, http:// www.voterguide.sos.ca.gov/past/2012/general/propositions/39/analysis.htm.

LXXIX California Secretary of State. Official Voter Information Guide. Proposition 30 Analysis by the Legislative Analyst, November 2012, http:// www.voterguide.sos.ca.gov/past/2012/general/propositions/30/analysis.htm.

LXxx These are, as an example, the evaluations presented in the report of The Volker Alliance, Truth and Integrity in State Budgeting. Lessons from three States, Initial Report of the Truth and Integrity in Government Finance Project, New York, 2015, pp. 19-20.

LXXXI New York State Office of the State Comptroller, Economic Trends in New York State, October 2010; New York State Office of the State Comptroller, Economic Trends in New York State, May 2012; available at http://www.osc.state.ny.us.

LxxxII See The State Budget Crisis Task Force, New York Report, 2012, p. 15.

LXxxiII State Education Budget and Reform Act of 2007-Article VII (S.2107-C/A.4307-C).

LXxxiv New York State Legislative Law, Sec. 54.2.a. See, for example, Ravitch 2010; New York State Office of the State Comptroller, Fiscal Update: Closeout Analysis of SFY 2009-10 April 2010, p. 3, http://www.osc.state.ny.us/reports/budget/2010/yearend0410.pdf.

Lxxxv See The State Budget Crisis Task Force, New York Report, 2012, p. 18.

LXXXVI N.Y. Const. Art. VII $\int 4$.

LXXXVII Potaki v. New York State Assembly, 4 N.Y.3d at 82-83.

LXxxvIII Potaki v. New York State Assembly, 4 N.Y.3d at 89-101.

LXXXIx It became also possible to insert substantive law changes in the budget bills and force in such way a legislative approval. see Briffault 2009: 432-436. 


\begin{abstract}
xc New York State Office of the State Comptroller, Fiscal Update: Closeout Analysis of SFY 2009-10, 2010, pp. 1-5. XCI Wein v. Carey, 41 N.Y.2d 498, 504 (N.Y. 1977).

xCII See The State Budget Crisis Task Force, New York Report, pp. 18-20.

XCII As an example in 2009 the state borrowed over two billion dollars to finance the current service of state employees, Institute For Truth in Accounting, The Truth About Balanced Budgets: A Fifty State Study, State Data Lab 25, 2009, p. 27.

xCIV IGPA Fiscal Futures Project at http://igpa.uillinois.edu/fiscalfutures.

XCV See The State Budget Crisis Task Force, Illinois Report, 2012, p. 15.

XCVI Illinois temporary avoided the first problem, by manipulating funds. At the end $\mathrm{t}$ fails to make Medicaid payments to health care providers in order to make the budget appear balanced, despite Medicaid receiving insufficient funding. State Medicaid Programs Face Funding Challenges, FISCAL FOCUS 1, 3-6, 2008), available at http://www.ioc.state.il.us/index.cfm/resources/fiscal-focus/july-2008-medicaid/.

XCVII See The State Budget Crisis Task Force, Illinois Report, p. 19. For example, Illinois had delayed payments to such an extent that the state comptroller announced in 2008 that there was an unprecedented billions of dollars worth of backlog of deferred payments. The Section 25 Budget "Loophole," FISCAL Focus 7, 2008, available at http://www.ioc.state.il.us/index.cfm/resources/fiscal-focus/july-2008-medicaid/,
\end{abstract}

XCVIII Illinois Constitution (Art. VIII, Sec. 2).

XCIX Illinois government adopted a fund sweeping in 2009 when the governor proposed to move $\$ 350$ million from the state trust fund, which does not need to be balanced, to the state general fund, which does need to be balanced, See Institute For Truth in Accounting, The Truth About Balanced Budgets 27-28.

C See The State Budget Crisis Task Force, Illinois Report, pp. 28-31.

CI See The State Budget Crisis Task Force, Illinois Report, p. 21.

CII See for example, CLEAN v. State, 928 P.2d 1054, 1061 (Wash. 1996), Richmond, 643 P.2d at 945; see also City \& County of San Francisco v. Farrell, 648 P.2d 935, 938 (Cal. 1982).

CIII See for example, Fent v. Okla. Capitol Improvement Auth., 984 P.2d 200,204 (Okla. 1999); Wilson v. Ky. Transp. Cabinet, 884 S.W.2d 641, 646 (Ky. 1994).

CIV According to Croley 1995: 725-726, in thirty-eight states, most or all judges are elected.

CV See for example, WDW Props., Inc. v. City of Sumter, 535 S.E.2d 631, 635-36 (S.C. 2000), finding that "economic welfare is one of the main concerns of the city, state, and the federal government".

Cvi See Employers Ins. Co. of Nev. v. State Bd. of Exam'rs, 21 P.3d 628, 633 (Nev. 2001).

CVII For others examples of courts adopting this interpretative behaviour, see McCrane, 292 A.2d at 557 (quoting Clayton v. Kervick, 244 A.2d 281, 288 (N.J. 1968)); Dieck v. Unified Sch. Dist. of Antigo, 477 N.W.2d 613,619-20 (Wis. 1991); see also In re Okla. Improvement Auth., 958 P.2d 759, 763 (Okla. 1998) holding that "[i]t is not unconstitutional to accomplish a desired result, lawful in itself, by innovative legal measures".

CVIII This element particularly emerged in the analysis of the New York State budget troubles after the crisis, look supra, Sec. III, par. ii).

CIX It is also possible to see a close connection between fiscally conservative states and strict rules: considering the budgetary rules as a self-commitment, in which the endogeneity issue almost deletes the real limiting effects of those rules (See Briffault 1996: 60). This helps to explain why the more recent constraints seem more effective than the older - classically, debt limit - ones. The main role of the political factors in determining the budget policy, considering the legal weakness of the institutional framework has been particularly emphasized in Briffault 2003: 955-957.

CX But it is important to note that rules become an effective constraint on policies only when they are not merely an expression of society's preferences; in that case they tend to be perceived, most of all, as obstacles by the relevant political actors, particularly because of the difficulty to change them, see Alesina and Perotti 1996. 
References

- Alesina Alberto and Perotti Roberto, 1996, Budget Deficits and Budget Institutions, NBER Working Paper 5556, 1996.

- Alt James E. and Lowry Robert C., 1994, "Divided Government, Fiscal Institutions and Budget Deficits: Evidence from the States", American Political Science Review, LXXXVIII(4): 811-828.

- Bohn Henning and Inman Robert P., 1996, Balanced-Budget Rules and Public Deficits: Evidence from the U.S. States, Carnegie-Rochester Conference Series on Public Policy 45, 1996.

- Briffault Richard, 1996, Balancing Acts. The Reality Bebind State Balanced Requirements, Twentieth Century Fund Press, New York.

- Briffault Richard, 2003, "Foreword: The Disfavored Constitution: State Fiscal Limits and State Constitutional Law”, Rutgers Law Journal, XXXIV(4): 907-957.

- Briffault Richard, 2009, "Courts, Constitutions and Public Finance. Some Recent Experiences from the States", in Garrett Elizabeth, Graddy Elizabeth A. and Jackson Howell E. (eds), Fiscal Challenges. An Interdisciplinary Approach to Budget Policy, Cambridge University Press, 418-445.

- $\quad$ Bunch Beverly S., 1991, "The Effect of Constitutional Debt Limits on State Governments' Use of Public Authorities", Public Choice, LXVIII(1/3): 57-69.

- Clingermayer James C. and Wood B. Dan, 1995, "Disentangling Patterns of State Debt Financing", American Political Science Review, LXXXIX(1): 108-120.

- $\quad$ Council of State Governments, 2008, The Book of the States 2008, vol. 40/2008.

- Croley Steven P., 1995, “The Majoritarian Difficulty: Elective Judiciaries and the Rule of Law", University of Chicago Law Review, LXII(2): 689-794.

- $\quad$ English William B., 1996, "Understanding the Costs of Sovereign Default: American State Debts in the 1840", American Economic Review, LXXXVI(1): 259-275.

- $\quad$ Eucalitto Cory, 2013, Unbalanced: Why State Balanced Budget Requirements Are Not Enough, STATE BUDGET SOLUTIONS, http://www.statebudgetsolutions.org/doclib/20130403 UnbalancedPDF.pdf.

- Galles Gary M. and Sexton Robert L., 1998, "A Tale of Two Tax Jurisdictions: The Surprising Effects of California's Proposition 13 and Massachusetts' Proposition 21/2”, American Journal of Economics and Sociology, LVII(2): 123-133.

- Gillette Clayton P., 2004, "Direct Democracy and Debt", XXX Journal of Contemporary Legal Issues, New York University Public Law and Legal Theory Research Paper Series, Research Paper No. 69.

- Greve Michael S., 2012, “Our Federalism Is Not Europe’s. It’s Becoming Argentina's”, Duke Journal of Constitutional Law \& Public Policy, VII(1): 17-42.

- Hellerstein Jerome R. and Hellerstein Walter, 1997, State and Local Taxation: Cases \& Materials 34, 6th ed., West Group, St. Paul, MN.

- Henning C. Randall and Kessler Martin, 2012, Fiscal Federalism: US history for Architects of Europe's Fiscal Union, in Peterson Institute for International Economics Working Paper Series, January 2012.

- Hou Yilin and Smith Daniel L., 2006, "A Framework for Understanding State Balanced Budget Requirement Systems: Reexamining Distinctive Features and an Operational Definition", Public Budgeting and Finance, XXVI(3): 22-45.

- Hou Yilin and Smith Daniel L., 2009, "Do State Balanced Budget Requirements Matter? Testing Two Explanatory Frameworks", Public Choice, CXLV(1): 57-79.

- Institute For Truth in Accounting, 2009, The Truth About Balanced Budgets: A Fifty State Study, State Data Lab 25.

- Knight Brian G., 2000, "Supermajority Voting Requirements for Tax Increases: Evidence from the States", Journal of Public Economics, LXXVI(1): 41-67.

- Luppino-Esposito Joe, 2014, The Worst State Budget Gimmicks of 2013, STATE BUDGET SOLUTIONS, http://www.statebudgetsolutions.org/publications/detail/the-worst-state-budget-gimmicksof-2013.

- Lusvardi Wayne, 2011, Calif. Gov. Jerry Brown Debt Gimmicks 'Balance' Budget, WATCHDOG.ORG (June 14, 2011), http://watchdog.org/9892/calif-gov-jerry-brown-debt-gimmicks$\% \mathrm{E} 2 \% 80 \% 98$ balance $\% \mathrm{E} 2 \% 80 \% 99$-budget. 
- Mahdavi Saeid and Westerlund Joakim, 2011, "Fiscal Stringency and Fiscal Sustainability: Panel Evidence from the American State and Local Governments", Journal of Policy Modelling, XXXIII(6): 953-969.

- Marino Richard J. and Waddell Colleen, 2001, Revised Lease and Appropriation-Backed Debt, STANDARD \& PooR's RATING SERVICES, June 13, 2001.

- McCall H. Carl, 1996, Fiscal Review of the Enacted 1995-1996 Budget, News from the Office of the New York State Comptroller.

- $\quad$ McGrane Reginald C., 1935, Foreign Bondholders and American State Debts, Macmillan, New York

- Musso Juliet Ann, Graddy Elizabeth A. and Bravo Grizard Jennifer, 2009, "Budgetary Arrangements in the 50 States: In Search of Model Practices", in Garrett Elizabeth, Graddy Elizabeth A. and Jackson Howell E. (eds), Fiscal Challenges. An Interdisciplinary Approach to Budget Policy, Cambridge University Press, 251270.

- National Association of State Budget Officers, 2008, Budget Processes in the States, Washington, D.C. NASBO, and the following reports available at https://www.nasbo.org/budget-topics/state-budgetprocesses.

- National Conference of State Legislatures, 1996, State Balanced Budget Requirements: Executive Summary, available at http://www.ncsl.org/research/fiscal-policy/state-balanced-budget-requirements.aspx.

- National Conference of State Legislatures, 2010, NCSL Fiscal Brief: State Balanced Budget Provisions, October 2010.

- Nowlan James D., Gove Samuel K. and Winkel Richard J., 2010, Illinois Politics. A Citizen's Guide, University of Illinois Press, Champaign, IL.

- O’Connor Evan, 2015, “Caught Off-Balance: How Implementing Structural Changes to State Balanced Budget Requirements Can Foster Fiscal Responsibility and Promote Long-Term Economic Health", British Columbia Law Review, LXVI(1): 351-388.

- $\quad$ Pinsky David E., 1963, "State Constitutional Limitations on Public Industrial Financing: An Historic and Economic Approach", University of Pennsylvania Law Review, CXI(3): 265-327.

- Poterba James M., 1997, “Do Budget Rules Work?”, in Auerbach Alan J. (ed), Fiscal Policy: Lessons from Economic Research, MIT Press, Cambridge, MA, 53-86.

- Poterba James M. and Rueben Kim S., 1999, "State Fiscal Institutions and the U.S. Municipal Bond Market", in Poterba James M. (ed), Fiscal Institutions and Fiscal Performance, University of Chicago Press, Chicago, IL, 181-208.

- $\quad$ Ratchford B.U., 1941, American State Debts, Duke University Press, Durham, NC.

- $\quad$ Ravitch Richard, 2010, A Five-Year Plan to Address the New York State Budget Deficit, March 20, http://www.rockinst.org/pdf/budgetary balance ny/2010-03-10-LG FYFP.pdf.

- Rodriguez Tejedo Isabel and Wallis John Joseph, 2012, "Fiscal Institutions and Fiscal Crises", in Conti Brown Peter and Skeel David A. Jr., When States Go Broke: The Origin, Context, and Solutions for the American States in Fiscal Crisis, Cambridge University Press, Cambridge, UK, 9-39.

- Rubin Dale F., 1993, "Constitutional Aid Limitation Provisions and the Public Purpose Doctrine", Saint Louis University Public Law Review, XII(1): 143-167.

- $\quad$ Schragger Richard C., 2012, "Democracy and Debt”, The Yale Law Journal, CXXI(4):860-886.

- Sexton Terri A. et al., 1999, "Proposition 13: Unintended Effects and Feasible Reforms", National Tax Journal, LII(1): 99-112.

- Shadbegian Ronald J., 1996, "Do Tax and Expenditure Limitations Affect the Size and Growth of State Government?", Contemporary Economic Policy, XIV(1): 22-35.

- Skeel David A. Jr., 2012, "State Bankruptcy from the Ground Up", in Conti Brown Peter and Skeel David A. Jr., When States Go Broke: The Origin, Context, and Solutions for the American States in Fiscal Crisis, Cambridge University Press, Cambridge, UK, 191-213.

- $\quad$ Skidmore Mark, 1999, "Tax and Expenditure Limitations and the Fiscal Relationships Between State and Local Governments", Public Choice, XCIX(1/2): 77-102.

- $\quad$ Sterk Stewart E. and Goldman Elizabeth S., 1991, "Controlling Legislative Shortsightedness: The Effectiveness of Constitutional Debt Limitations", Wisconsin Law Review, issue 6: 1301-1368.

- Tobin Donald B., 1996, "The Balanced Budget Amendment: Will Judges Become Accountants? A Look at State Experiences", Journal of Law \& Politics, XII(2): 153-193. 
- Topinka Judy Baar, 2001, “Comptroller of Illinois, Revenue Grows, Bill Backlog Remains”, The Illinois State Comptroller's Quarterly, 6, 2012, at http://www.ioc.state.il.us/index.cfm/linkservid/A1F6980B-1CC1DE6E-2F488540A8DB45B3/showMeta/0/.

- U.S. General Accounting Office, (1995), Balanced Budget Requirements: State Experiences and Implications for the Federal Government (GAO/AFMD-93-58BR, Washington, D.C.: GAO, 1995), available at http://archive.gao.gov/d44t15/148877.pdf.

- $\quad$ Valente William D. et al., Cases and Materials on State and Local Government Law, 5th ed., West Group, St. Paul, MN.

- Wallin Bruce A., 1995, "Massachusetts: Downsizing Government”, in Gold Steven D. (ed), The fiscal crisis of the states: Lessons for the future, Georgetown University Press, Washington, DC, 252-295.

- Wallis John Joseph, 2002, Constitutions, Corporations, and Internal Improvements: American States, 1842-1852, Unpublished Manuscript, University of Maryland Department of Economics.

- Wetterich Chris, 2011, “Supreme Court OK's fund 'sweeps' to balance state budget”, The State JournalRegister, October 31, 2011.

- White James H. III, 2002, "Constitutional Authority to Issue Debt", Cumberland.Law Review, XXXIII(2): 561-574.

- Williams Bob, 2013, Reality-Based Budgeting: How to Permanently Resolve State Budget Gaps, STATE BUDGET SOLUTIONS, http://www.statebudgetsolutions.org/publications/detail/reality-based-budgetinghow-to-permanently-resolve-state-budget-gaps.

- Wolman Harold L. and Peterson George, 1981, "State and Local Government Strategies for Responding to Fiscal Pressure", Tulane Law Review, LV(3): 773-819. 